\title{
Marching In: China's Cultural Trade in Official and Press Discourse
}

\section{Rogier Creemers}

\section{(2) OpenEdition \\ 12 Journals}

Electronic version

URL: http://journals.openedition.org/chinaperspectives/5802

DOI: 10.4000/chinaperspectives.5802

ISSN: 1996-4617

\section{Publisher}

Centre d'étude français sur la Chine contemporaine

\section{Printed version}

Date of publication: 30 March 2012

Number of pages: 29-37

ISSN: 2070-3449

\section{Electronic reference}

Rogier Creemers, «Marching In: China's Cultural Trade in Official and Press Discourse», China Perspectives [Online], 2012/1 | 2012, Online since 30 March 2015, connection on 28 October 2019.

URL : http://journals.openedition.org/chinaperspectives/5802 ; DOI : 10.4000/chinaperspectives.5802

(C) All rights reserved 


\title{
Marching In: China's Cultural Trade
} in Official and Press Discourse

\author{
ROGIER CREEMERS*
}

\begin{abstract}
This essay analyses the official and media response to the WTO cases related to cultural products, which China lost. It aims to contextualize both the official discourse and the press discourse in terms of domestic politics and China's trade priorities. It concludes that in the official discourse, China and the US are working at cross purposes, as they have fundamentally divergent concepts of trade in cultural products. The newspaper discourse is more moderate and emphasises developmental and commercial issues, but is also subject to the priorities of Chinese politics.
\end{abstract}

KEYWORDS: China, WTO, cultural trade, intellectual property rights, political discourse, press.

$\mathrm{T}$ he trade in cultural products remains one of the most persistent points of contention between China and its trading partners. Since the beginning of the ' 90 s, continuing high rates of media piracy, the relatively low import quota for motion pictures and the various barriers erected against foreign participation in the media market have brought the Hollywood lobby to press for trade pressure against China. This led to three episodes in which the United States Trade Representative (USTR) threatened to sanction China for its alleged failure to protect US intellectual property rights. Trade wars were only narrowly averted each time, after protracted negotiation. As a result, China swiftly instituted comprehensive intellectual property legislation and enforcement mechanisms. ${ }^{(1)}$

It also provided an extra stimulant for China to gain WTO membership. While China had started accession procedures to GATT in 1986 already, the post- Tiananmen environment had lent extra urgency to this issue. After 1989, the leftist wing of the Party had retrenched its ideological and economic position, until Deng Xiaoping used his "southern tour (nanxun 南巡) to continue the market-based reform process. As the Party would henceforth base its legitimacy on economic performance, WTO accession was a means to ensure that China - through its export-based growth model, would become so reliant on the market economy and foreign trade, that it would become impossible to turn the reforms back. (2) In China's international politics, joining the GATT (and later, the WTO) also had another big boon. Its multilateral nature, and the WTO Dispute Settlement Mechanism would protect China from having to go through arduous bilateral trade negotiations on a regular basis, and from a non-renewal of its Most-Favoured Nation status by the US Congress.

At the same time, the post-Tiananmen environment that stimulated external trade, had also demonstrated to the leadership that control over public communication - which had lessened during the Eighties - had to be reasserted in order to prevent further organized dissent. ${ }^{(3)}$ Furthermore, the leadership had been severely shocked by the abrupt end of Communism in Eastern Europe, which it largely ascribed to Western "peaceful evolution" efforts. ${ }^{(4)}$ Hence, in the area of audio-visual media, the priority remained to keep foreign influence to a minimum. Concern about the ability of the Chi- nese cultural sector to withstand a foreseen onslaught by Hollywood further strengthened this resolve. ${ }^{(5)}$ This is reflected in China's services commitments: while the import quota for foreign films were raised to 20 per year, foreign media enterprises would be limited to minority participation in joint ventures, in certain designated areas which were less sensitive, or where the leadership wished to acquire foreign know-how and technology. The resulting situation - persistent high rates of piracy and low returns from the increasingly enticing Chinese market - frustrated Hollywood, and illustrated the conflict between the fundamentally differing vision of cultural products between the US and China. Where Hollywood's ambitions are mainly commercial, requiring an open market, China sees media products as important political tools, requiring control.

This frustration led to the USTR filing two requests for consultations in 2007. DS362, China - Intellectual Property Rights and DS363, China Audio-visual Products and Services. These respectively called into question denial of copyright to unauthorized products and criminal enforcement thresholds, and a number of import and distribution barriers discriminating against non-Chinese media enterprises. As such, they are not "typical" trade cases, neither in terms of product covered (films, television programmes and music), nor - to a certain extent - in terms of the specific measures addressed. They are at the nexus of interrelated aspects of international and

Rogier Creemers is researcher, Programme for Comparative Media Law and Policy, University of Oxford.

1. A general overview of the Sino-US relationship in the light of piracy is available in Peter Yu, "Still Dissatisfied After All These Years: Intellectual Property, Post-WTO China, and the Avoidable Cycle of Futility," Georgia Journal of International and Comparative Law, vol. 34, 2005, and Andrew C. Mertha, The Politics of Piracy: Intellectual Property in Contemporary China, Ithaca, Cornell U.P., 2005.

2. Tony Saich, "China as a Member of the WTO: Some Political and Social Questions," Harvard University, Kennedy School of Government Working Paper, 2002.

3. Susan Shirk, "China: Fragile Superpower: How China's Internal Politics Could Derail Its Peaceful Rise," Oxford, Oxford University Press, 2007.

4. David Shambaugh, China's Communist Party, Atrophy and Adaptation, Berkeley, California University Press, 2008, p. 74.

5. See, for example, Yahong Li, "The Wolf Has Come: Are China's Intellectual Property Industries Prepared for the WTO?," UCLA Pacific Basin Law Journal, vol. 20, 2002. 
domestic politics, both in the United States and China, involve complex questions which, according to some observers, are on or even over the edge of what the WTO should concern itself with, ${ }^{(6)}$ and illustrate the potential conflict between a trade order established on liberal economic principles and Chinese authoritarianism. ${ }^{(7)}$

This essay aims to provide a better understanding of how this tension is perceived in the Chinese media and what this can tell us about the future developments of the Chinese media regime. This article is structured in the following way. First, I will provide a brief overview of both cases concerned. Second, I will analyze the official discourse concerning these cases, paying particular attention to where both parties in the dispute lay the emphasis, and contextualizing these in the broader framework of Sino-US relations. Third, I will outline how these cases are presented in the Chinese media; what the expected and preferred outcomes are, and which position this takes in the broader picture of Chinese media policy, in order to shed more light on how this discourse may function in agenda-setting, policymaking and change.

\section{The cases}

Since the late Eighties, piracy and counterfeiting had been a bone of contention between China and other trade partners, particularly the United States. Since then, China created a comprehensive legislative framework that largely complied with international standards, and after 2001, with China's WTO commitments. Also, significant resources were dedicated to anti-piracy and counterfeiting enforcement efforts. In fact, few countries in the world spend more per capita on IPR enforcement than China. ${ }^{(8)} \mathrm{How}$ ever, counterfeiting and piracy remained rampant, particularly in the media and software sector. ${ }^{(9)}$ Apart from piracy, Hollywood was also increasingly irritated by the barriers erected against foreign presence in the Chinese media market, exemplified by the screening quota for foreign cinema films, ${ }^{(10)}$ but which also entail restrictions on market access for products and operators, investment restrictions, censorship and content review procedures, etc. ${ }^{(11)}$ In 2007, the USTR took the decision to file a request for consultations - the first step on the road to a WTO dispute - in two cases, DS362, concerning copyright law and enforcement standards and DS363, concerning market access for media products and operators.

There were two main US claims in DS362. First, it was claimed that Article 4 of the 2001 Chinese Copyright Law - which stated that works of which publication was prohibited, would not be protected by copyright law - violated the prohibition of formalities for copyright grant present in the Berne Convention, incorporated into WTO law by Article 9(1) TRIPS (Trade-related aspects of intellectual property rights). Second, quantitative thresholds for criminal copyright prosecution were alleged to exceed the standard in Article 61 TRIPS that criminal punishment must be available "at least in cases of wilful trademark counterfeiting or copyright piracy on a commercial scale." (12) A third, less important claim, concerned measures to dispose of counterfeiting products after removal of the counterfeited trademark.

In this case, both sides scored a number of points. The Panel ruled that the wording of Article 4, as well as the counterfeiting disposal rules, violated WTO rules. It also found that the US had not brought sufficient evidence to prove the empirical point that the minimum criminal enforcement standards against copyright piracy indeed exceeded the definition of "commercial scale." The Panel Report was not appealed, and the findings of the Panel were quickly implemented. ${ }^{(13)}$ This was possible because updating the in- consistent rules was relatively easy. In the case of the Copyright Law, Article 4 was updated to state that rights holders are required to exercise their copyright in accordance with the law, and that the State institutes a censorship regime.

In comparison, DS363 was a much larger case. It concerned a plethora of Chinese measures that were aimed to prevent foreign works and foreign actors from accessing the Chinese market. They were grouped under four major headings: trading rights under the Accession Protocol, market access commitments under Article XVI GATS, national treatment under Article XVII GATS and national treatment under Article III:4 GATT. (14) The claims concerned a variety of product areas, including cinema films, audio-visual products, publications and on-line music, and addressed issues related to barriers on company establishment, investment, import and distribution. In other words, DS363 struck at the heart of the Chinese foreign media control regime. ${ }^{(15)}$ China's defence was partly built on procedural grounds, and it successfully managed to exploit a number of procedural errors by the US. It also invoked on cultural exception as present in Article XX(a) GATT 1994. The US furthermore did not sufficiently argue a number of claims, leading to these not being considered by the Panel. ${ }^{(16)}$ Apart from these, the US won across the board, as the Panel found that the measures at issue violated China's accession commitments and general WTO discipline.

In contrast to the IP case, DS363 was appealed by both China and the US. China argued that trading rights commitments do not apply to cinema films and unfinished audio-visual products, that it could invoke the cultural exception in Article XX(a) GATT 1994 in a claim concerning the AP, and it disputed the scope of the GATS schedule entry on "sound recording distribution services," claiming that this did not include on-line distribution. The US challenged the finding of the Panel that the requirement to conform to State planning, as present in a number of Chinese regulations, is necessary to protect public morals. The Appellate Body upheld most findings of the Panel, with the exception of finding that the cultural exception can be claimed with respect to the $\mathrm{AP}$, and that the state plan requirement is not necessary for the protection of public morals.

6. Jingxia Shi, Weidong Chen, "The 'Specificity' of Cultural Products versus the 'Generality' of Trade Obligations - Reflecting on 'China_Publications and Audiovisual Products,"' Yale Law School Student Scholarship Papers, 2010, passim.

7. Julia Ya Qin, "Pushing the Limits of Global Governance: Trading Rights, Censorship and WTO Jurisprudence - A Commentary on the China-Publications Case," Chinese Journal of International Law, vol. 10, no. 2, 2011, pp. 1-62.

8. Martin Dimitrov, Piracy and the State: the Politics of Intellectual Property Rights in China, Cambridge, Cambridge University Press, 2008

9. IIPA report, 2011.

10. In 1994, the State Administration of Radio, Film and Television (SARFT) had approved the importation of 10 films per year.

11. A detailed overview of these restrictions is available in Rogier Creemers, Explaining Audiovisual Media Piracy in China: Media Control, Enforcement and Globalization, Ph.D. thesis, Maastricht University, 2012, Chapter IV.

12. Article 61TRIPS.

13. Implementation Report. WT/DS362/14.

14. A fifth claim concerned national treatment under the Accession Protocol, but as a finding of inconsistency with Article III:4 GATT is a prerequisite for a finding of inconsistency under the AP, this claim was not addressed by the Panel.

15. It is important to keep in mind that the Chinese media regime is not solely concerned with foreign products, actors and services. While there are subject to stronger regulation in a number of areas, the domestic media market is very rigidly controlled as well, as the Party-State considers media control to be of the essence of its survival. See also David Shambaugh, "China's Propaganda System: Institutions, Processes and Efficacy," The China Journal, no. 57, 2007, and Anne-Marie Brady, Marketing Dictatorship: Propaganda and Thought Work in Contemporary China, Lanham, Rowman \& Littlefield, 2010.

16. See Rogier Creemers, "Summary of and Comment on the Panel Report of DS363," working paper, 2009, available on SSRN. 
Again in contrast with DS362, the findings of DS363 were never fully implemented. Cosmetic updates were made to a number of regulations, ${ }^{(17)}$ which only cosmetically addressed the findings of the Panel, and did not meaningfully address the issues underlying the US case. Rather, the US and China came to an agreement.

\section{The official discourse}

A lot about the underlying attitudes towards the international trading system can be deduced from the official discourse concerning the two cases at issues. In dispute settlement, there are three major phases. The first is the initiation of the dispute, which proceeds in two stages: a request for consultations and a panel request. The second stage is the Panel stage, ending in the publication of the Panel Report. In the majority of cases, the case will then proceed to the Appellate Body. ${ }^{(18)}$ The dispute can end at any stage, and it is up to the complainant to decide to proceed to the consultation and Panel stages, while the respondent may also appeal a Panel Report.

The official discourse concerning DS362 and DS363 can be situated in these three stages. When the two requests for consultations were filed, the US Trade Representative stated that:

Piracy and counterfeiting levels in China remain unacceptably high. Inadequate protection of intellectual property rights in China costs U.S. firms and workers billions of dollars each year, and in the case of many products, it also poses a serious risk of harm to consumers in China, the United States and around the world. We acknowledge that China's leadership has made the protection of intellectual property rights a priority and has taken active steps to improve IPR protection and enforcement. However, while the United States and China have been able to work cooperatively and pragmatically on a range of IPR issues, and China has taken numerous steps to improve its protection and enforcement of intellectual property rights, we have not been able to agree on several important changes to China's legal regime that we believe are required by China's WTO commitments. Because bilateral dialogue has not resolved our concerns, we are taking the next step by requesting WTO consultations. [...] In the same vein, we have discussed with China in detail the harm to U.S. industries, authors and artists who produce books, journals, movies, videos, and music caused by limiting the importation of these products to Chinese state-owned entities, and the problems caused by Chinese laws that hobble the distribution of foreign home entertainment products and publications within China. These products are favorite targets for IPR pirates, and the legal obstacles standing between these legitimate products and the consumers in China give IPR pirates the upper hand in the Chinese market. ${ }^{(19)}$

The Chinese response to this was regretful. The Ministry of Commerce issued a statement claiming that:

The Chinese government's attitude towards intellectual property rights protection has always been resolute, and its achievements obvious to all. [...] This runs against the consensus reached between the two countries' leaders as to developing bilateral trade relations and properly handling trade problems.

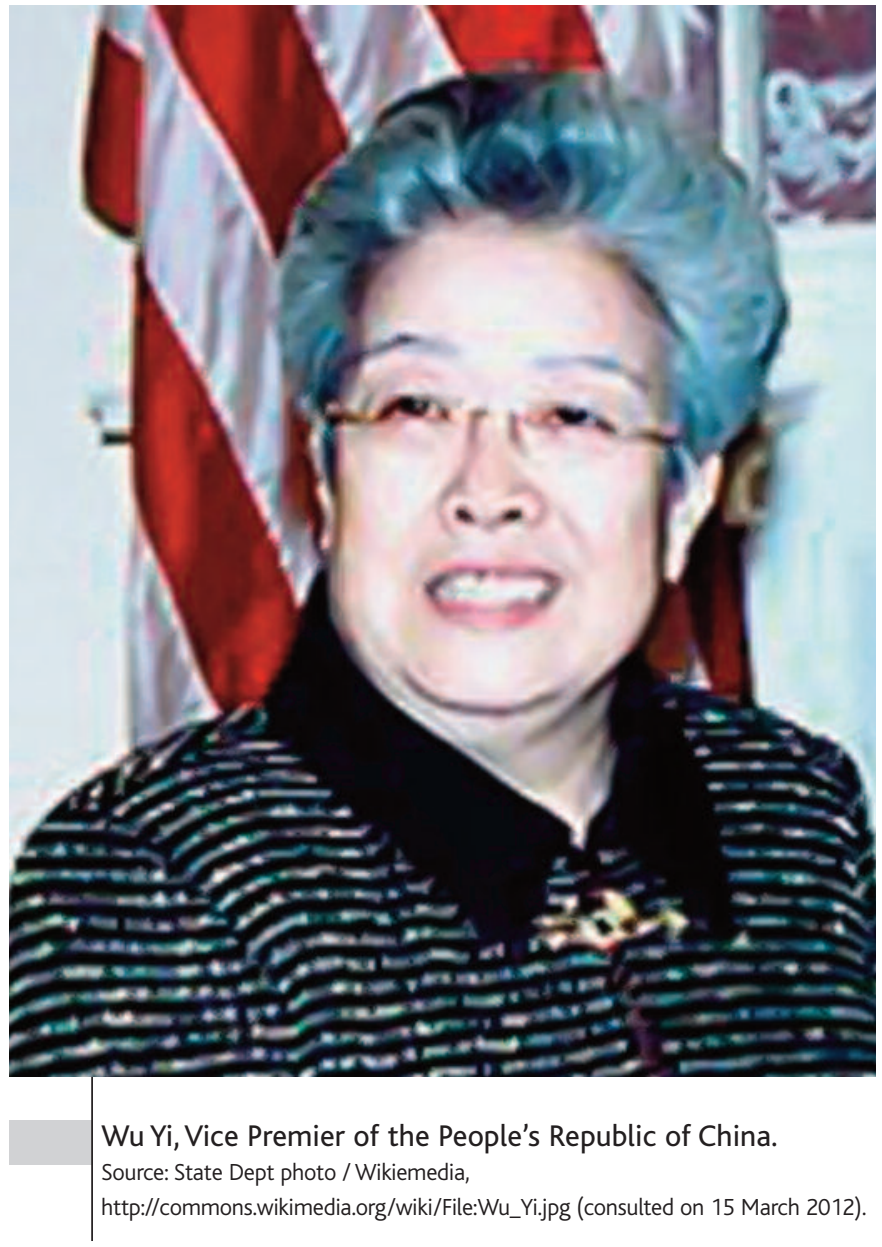

Furthermore, it said the action would "seriously damage the two countries' established cooperation and bring an unfavourable impact on bilateral trade." (20)

Later, Chinese vice-premier Wu Yi stated that:

"The USTR, has totally ignored the massive strides China has made. [The US action] flies in the face of the agreement between the two country's leaders to propose dialogue as a way of settling disputes. [...] This will have an utterly negative impact and will inevitably badly damage bilateral intellectual property cooperation," she said, also warning it would "harm" cooperation over market access issues. (21)

17. See, for example, Yinxiang zhipin jinkou guanli banfa [Audiovisual Product Import Management Rules], General Administration of Press and Publications; General Administration of Customs, 2011, and the Waishang touzi chanye zhidao mulu (2011 nian xiuding) [Foreign Investment Industry Guidance Catalogue (2011 Revision)], National Development and Reform Commission; Ministry of Commcerce 2011. Translations of these documents are available on the author's web site: http://chinacopyrightandmedia.wordpress.com (consulted on 6 March 2012).

18. In about two thirds of cases that go to the Panel stage, an appeal is filed. World Trade Organization, Dispute Settlement - Statistics, retrieved on 8 December 2011, www.wto.org/english/tratop_e/ dispu_e/stats_e.htm (consulted on 6 March 2012).

19. "United States Files WTO Cases Against China Over Deficiencies in China's Intellectual Property Rights Laws and Market Access Barriers to Copyright-Based Industries," USTR press release, 9 April 2007.

20. "China Slams USWTO Piracy Action," China Daily, 11 April 2007.

21. "Wu: US Piracy Case Will Harm Trade Ties," PRC Permanent Mission to the WTO, 25 April 2007, http://wto2.mofcom.gov.cn/aarticle/chinanews/200704/20070404610716.html (consulted on 6 March 2012). 


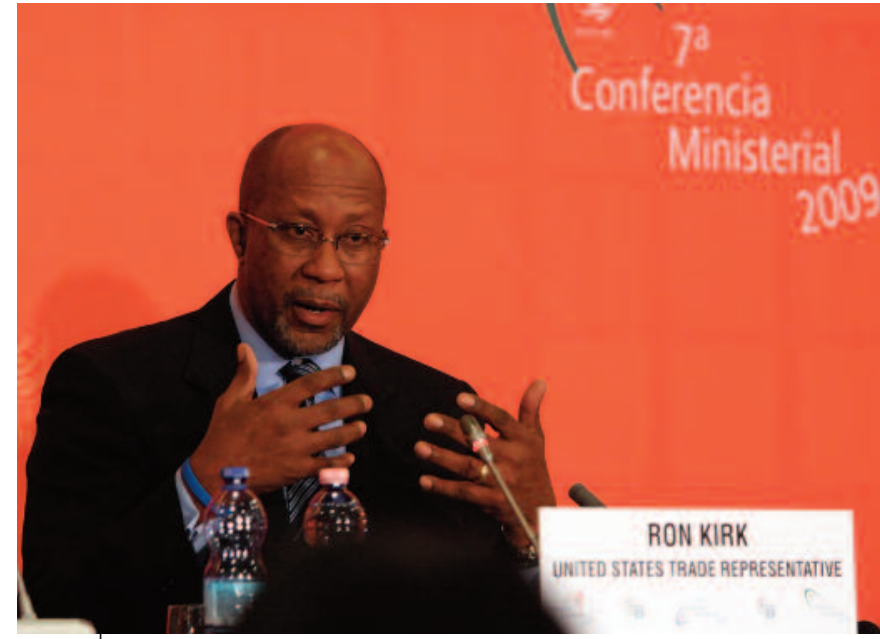

Ron Kirk, U.S. Trade Representative, speaking at a press conference following the conclusion of the 7th WTO Ministerial Conference in Geneva, Switzerland.

Source: U.S. Mission Geneva: Eric Bridiers/Wikimedia, http://commons.wikimedia.org/wiki/File:USTR_Ron_Kirk_-

_Press_Conference,_December_2.jpg (consulted on 15 March 2012).

The DS362 Panel Report was completed first, and its conclusions were received relatively well by both sides. The United States stated that:

Today, a WTO panel found that a number of deficiencies in China's IPR regime are incompatible with its WTO obligations. These findings are an important victory [...] Having achieved this significant legal ruling, we will engage vigorously with China on appropriate corrective actions to ensure that U.S. rights holders obtain the benefits of this decision [...] The Panel did find, however, that it needed more evidence in order to conclude that actual thresholds for prosecution in China's criminal law are so high as to allow commercialscale counterfeiting and piracy to occur without the possibility of criminal prosecution. While this conclusion is disappointing, the United States is encouraged that the Panel, facing a case of first impression, set forth a market-based analytical approach that should help WTO Members and panels avoid or resolve future disputes concerning obstacles to criminal enforcement against counterfeiting and piracy. ${ }^{(22)}$

The Chinese side also claimed victory. MOFCOM claimed a "the expert group report rebutted the great majority of the US side's claims and broadly vindicated China's intellectual property system." (23) Furthermore, MOFCOM maintained China's right to censor publications. As DS362 was not appealed, there was no further official communication concerning this case, save for a notice by the USTR when the Dispute Settlement Body adopted the Panel Report. This notice confirmed that the United States would use "all appropriate tools" to ensure that trading partners keep commitments, and that the US would remain constructively engaged with China on IPR protection. (24)

DS363, being more complex and striking close at the heart of one of the Chinese leadership's core interests, aroused more discussion. As the Panel Report was published, US Trade Representative Ron Kirk stated that:
Today, a WTO panel handed a significant victory to America's creative industries. [...] These findings are an important step toward ensuring market access for legitimate U.S. products in the Chinese market, as well as ensuring market access for U.S. exporters and distributors of those products. We will work tirelessly so that American companies and workers can fully realize the market opening benefits that this decision signals. [...] This decision promises to level the playing field for American companies working to distribute high- quality entertainment products in China, so that legitimate American products can get to market and beat out the pirates. To me, that is a clear win. We believe that this report will help pave the way toward more open trade between China and America. ${ }^{(25)}$

China, again, was less pleased with the outcome of the case, as Ministry of Commerce spokesperson Yao Jian indicated that China "regretted" (yihan 遗憾) the outcome of the cases, and considered filing an appeal. Yao further stated that:

China has always fulfilled its obligations on market access for publications, and the channels for foreign publications, films and audiovisual products to enter the Chinese market are extremely open" ( shifen changtong十分畅通). (26)

As indicated higher, both sides appealed the case, in which the majority of US claims were upheld. As a response to this, USTR Kirk stated that:

[...] America got a big win. [...] The Appellate Body's findings are key to ensuring full market access in China for legitimate, high-quality entertainment products and the exporters and distributors of those products. U.S. companies and workers are at the cutting edge of these industries, and they deserve a full chance to compete under agreed WTO rules. We expect China to respond promptly to these findings and bring its measures into compliance. [...] This case is also an important part of our efforts to combat intellectual property piracy. The panel and Appellate Body findings ensure that legitimate American products are granted market access so that they can get to market and beat out the pirates. This finding helps to ensure that America's creative ingenuity and innovation are protected abroad. (27)

The Chinese response was less positive. While it welcomed the clarification on some of the restrictions made in the Panel Report, as well as the affirmation of the exemption clause cited by the Chinese side in this case, the

22. "United States Wins WTO Dispute Over Deficiencies in China's Intellectual Property Rights Laws," USTR press release, January 2009.

23. "Shangwubu: Zhongmei zhishichanquan WTO zhengduan zhuanjiazu baogao bohuile Meifang de jueda bufen zhuzhang" [Ministry of Commerce: Expert Panel Report in Sino-US Intellectual Property Rights WTO Dispute Rejected Majority of US Arguments], Xinhua, 20 March 2009, http://news.xinhuanet.com/newscenter/2009-03/20/content_11044077.htm (consulted on 6 March 2012).

24. "World Trade Organization Adopts Panel Report in China - Intellectual Property Rights Dispute," USTR press release, March 2009.

25. "World Trade Organization Report Upholds U.S. Trade Claims Against China," USTR press release, August 2009

26. "WTO wei bohui guanyu Zhongguo chubanwu shichang zhunru suqiu," People's Daily, 14 August 2009.

27. "WTO Appellate Body Confirms Finding Against China's Treatment Of Certain Copyright-Intensive Products," USTR press release, December 2009. 
Chinese side regrets the other rulings made by the Appellate Body. The Chinese side further reiterated that after China joined the WTO, it earnestly implemented the duties under the WTO agreement in the area of publications market access, and that the channels for foreign publications, films and audiovisual products to enter the Chinese market are "fully open." (28) An official Xinhua press report further indicated that China had fully put forth the point of view that cultural products are special, and had requested the $A B$ to "respect the true meaning of members' services commitments (zunzhong chengyuan youguan fuwu chengnuo de zhenshi hanyi 尊重成员 有关服务承诺的真实含义)." (29) The special nature of cultural products is considered to be the fact that they combine commercial value and cultural value, and therefore should not be treated as general goods. Lastly, the report cited Beijing WTO Affairs Office deputy director Zhong Qing as stating that there was doubt about whether publications retail should be considered as goods or services, which would have consequences for China's treatment of foreign importers. ${ }^{(30)}$

\section{Evaluating the official discourse}

WTO cases can act as platforms for posturing for all parties involved in the dispute, both to domestic and international audiences. They can be used to show the national citizenry that their government stands up for the nation, interest groups that the incumbents serve their interests and foreign parties that the world trade game is taken seriously. Analyzing this discourse enables us to take a closer look at how China and the US consider the WTO as an institution and each other's position in the international trading system. I will in particular look at three aspects of the discourse: the perception of the WTO rules and procedures, the interests that both governments claim to defend and the assumptions that seem to underpin the posturing between both sides.

From the US point of view, the objective of the WTO is to create and sustain a rules-based trading system, which would benefit the United States' economy as well as those of other trading partners. This commitment is taken seriously in government ${ }^{(31)}$ as well as in industry. ${ }^{(32)}$ The discourse that is used in both areas emphasizes fairness and the benefits that obeying the rules bring to the United States. This implies that the United States voluntarily abdicates from a power-based negotiation model, in which its relative power would be much stronger than in a rules-based system. ${ }^{(33)}$ In the two cases, the United States are also clear that they are defending the US copyright industry, and in the audio-visual media industries in particular. They argue that Chinese measures, that violate the letter and spirit of the WTO agreements, damage legitimate interests of the industry, in particular due to losses related to piracy. At no point does the US claim that the market barriers themselves may be causes for losses to US enterprises. At the same time, by indicating the importance of the Sino-US relationship, the US also isolates this issue from other policy considerations.

The Chinese discourse, on the other hand, seems to characterize the WTO as a political, rather than legal body. First, it much less emphasizes the legal aspects of the American claims. By invoking the "consensus" on dealing with trade disputes, China seems to negate the United States' right to start WTO proceedings that all WTO members enjoy. Also, China seems to argue that the Chinese efforts to protect IPR should have been sufficient to warrant the US not bringing a case, regardless of any legal argument. Second, China seems to imply in its comments that the proceedings would damage broader Sino-US relationships. This may contravene the spirit of Article 3(10) of Dispute Settlement Understanding (DSU), which stipulates that com- plaints and counter-complaints in distinct matters should not be linked. (34) Third, China seems stubborn in stating the Chinese version of the facts, even after Panel or $A B$ have found otherwise. In particular, the statement that China has always implemented its WTO commitments, and import channels for media products are "fully open" seems particularly problematic. While China had by then learnt to be a better WTO litigator, ${ }^{(35)}$ it hadn't yet mastered the required diplomatic language. Fourth, at no point does the official discourse make clear what the reasons are for the market access barriers and the denial of copyright, or which interests are being defended. Lastly, it is interesting that China emphasizes its right to censor publications, even though this had not come under issue in either of the cases.

In short, the United States and China seem to be arguing different points, highlighting their respective declared priorities and ideas. The next question then became implementation and policy change on the Chinese side, particularly for DS363. In this respect, it is useful to find out whether and how this issue was addressed in the Chinese media. It is sometimes assumed that Chinese media function solely as a mouthpiece of the Party-State, indoctrinating the passive Chinese citizen with its own political message. Certainly, the Party-State has made it an objective to maintain a dominant position in the Chinese public debate and build popular support for its rule through mechanisms that Anne-Marie Brady refers to as "popular authoritarianism." (36) The questions here, however are rather more complex, as there are different interests that must be balanced. At the international level, China has made WTO compliance a priority, but the outcomes of DS363 directly concern highly sensitive political issues. Economically, there may be interests in China on different sides of the divide: cinema owners, for example, would benefit from increased importation of foreign films, and the same might be true for film distributors ${ }^{(37)}$ or television channels. On the other hand, Chinese content producers would likely be gravely harmed. (38)

28. "Shangwubu jiu Zhongmei chubanwu shichang zhunru WTO zhengduan an caijue fabiao tanhua," People's Daily, 24 December 2009.

29. "WTO jiu Zhongmei chuban shichang zhunru'an bohui Zhongfang shangsu" [WTO Rejects Chinese Appeal in Sino-US Publications Market Access Case], Caixin, 22 December 2009.

30. "WTO jiu Zhongmei chubanwu shichang zhunru an bohui Zhongfang shangsu," Xinhua, 22 December 2009.

31. See, for example, the speech of WTO Ambassador Punke at the 10th WTO trade policy review of the US: "Statement by Ambassador Michael Punke, Deputy United States Representative and Ambassador to the World Trade Organization," USTR speech, 29 September 2010. However, it is also argued that the American willingness to submit itself to an international rules-based system may partly stem from domestic political struggles between the executive and legislature. Rachel Brewster, "Rule-Based Dispute Resolution in International Trade Law," Virginia Law Review, vol. 92, 2006.

32. "International Agenda: Enforce Trade Agreements," US Chamber of Commerce, www.uschamber. com/international/agenda/enforce-trade-agreements (consulted on 6 March 2012).

33. Obviously, the power argument does not completely disappear within the WTO. Witness, for example, the different aspects of the US-Gambling case, in which the WTO permitted Antigua to suspend intellectual property obligations after the United States did not permit Antiguan service providers to provide on-line gambling services to US citizens.

34. See also in this special feature the article by Leilla Choukroune: China and the WTO Dispute Settlement System.

35. Henry Gao, "China in the WTO Dispute Settlement System: From Passive Rule-Taker to Active Rule-Maker?" in Ricardo Melendez-Ortiz, et al. (eds.), A Decade in the WTO: Implications for China and Global Trade Governance, Geneva, ICTSD, 2011.

36. For an in-depth study of the Party's propaganda strategy and a detailed overview of the term "populist authoritarianism," see Anne-Marie Brady, Marketing Dictatorship: Propaganda and Thought Work in Contemporary China, op. cit.

37. DS363 did not require film distribution to be opened up to foreigners, as China had not made corresponding commitments in its Services Schedule.

38. China may also keep the Taiwanese experience in mind:Taiwan progressively reduced import barriers for films, and finally abolished them altogether. Soon thereafter, Hollywood occupied 93 per cent of the Taiwanese box office intake. Michael Curtin, "The Future of Chinese Cinema: Some Lessons from Hong Kong and Taiwan," in Chin-Chuan Lee (ed.), Chinese Media, Global Contexts, Abingdon, Routledge, 2003 


\section{The press discourse after the cases}

As a relatively simple case, in which China didn't lose the most important issue, there was little newspaper analysis of DS362 after the case's conclusion. This was slightly different with DS363, as a number of articles appeared around the publication of the Panel and $A B$ reports evaluating the potential impact of the cases on the Chinese media sector. However, these articles were limited in scope: they concentrated mainly on the film sector, and some of them contained a number of factual mistakes, which influence the perception of the outcome of the cases.

\section{Factual mistakes}

One salient characteristic of a number of both Chinese and Western newspaper articles in these cases is the lack of factual understanding of both the content and implications of WTO rules and obligations. Some of these concern the relationship between import quota and moral concerns. China Daily writes, for example, "China imports 20 foreign films a year for theatrical release. The ruling, however, does not force China to let in products it thinks are harmful to public morals, which means the 20 -film quota stays." (39) Both premises are true, but the conclusion does not follow from them. The quota is there to control the aggregate impact of foreign films on China's economy, and is a Chinese commitment in its GATS schedule. China's right to censor refers to its ability to control individual works in the market. Conceivably, there are more than 20 films produced worldwide every year that would meet censorship requirements, but many of these do not enter Chinese cinemas due to quota restrictions.

A broader mistake is that the DS363 verdict somehow seems to imply that the film quota violates WTO norms and should be abolished. This is present in articles both on the Western side ${ }^{(40)}$ and on the Chinese side. ${ }^{(41)}$ While there are many good reasons to get rid of the quota, this case is not one of them, given that - as mentioned earlier - they are part of the corpus of Chinese WTO commitments. Any change to them would require an update of the WTO accession agreement. Apart from the question whether this is legally possible or not, it would seem logical that this would be part of a broader renegotiation of the Chinese terms of membership, which may be politically nearly impossible in the present economic climate. Another article mentions a Chinese promise to phase out film import quota by 2011. This promise is not present in the Chinese Services Schedule ${ }^{(42)}$ that lays down the quota, nor is it present in the Sino-US agreement that paved the way for Chinese accession. ${ }^{(43)}$ Nonetheless, even through the reports about these quotas are wrong, they may reflect the expectations of policymakers and the industry, and influence further film policies. It may also be a tactic to prepare actors on all sides for an easing of the quota, which might take pressure of other areas where the Dispute Settlement Body (DSB) did find incompliance. Lastly, the People's Daily writes that finding of incompliance would mean that China would have to accept retaliatory tariffs. ${ }^{(44)}$ While this may be true, it omits the possibility of compliance.

\section{Opening up the film sector}

By the time the Appellate Body made its decision in DS363, the Chinese cinema film sector had been growing at a rapid pace, which realigned the interests of different actors in the policy sphere. The number of cinemas has grown rapidly, as plans aimed to stimulate construction and renovation of cinemas nationwide are being progressively realized. This increase in screen real estate also requires more content, which in turn seems to cause increasing demands for films, including foreign films. At the time of the Panel decision, a number of articles were published which advocated for a more open media sector.

This position is reflected interestingly in the Nanfang Daily. This argued that opening media channels would not be a problem for censorship authorities, as they could simply expand to meet demand. Also, the paper stated that more competition would be good for the Chinese media sector, as it would push for better products. Assuaging potentially worried censors, and panning the inertia of government, it argued that allowing private capital into the television drama sector had provided better-received mainstream programmes than State actors had been. Finally, it asked the question how big the danger would be from foreign programmes, taking place far away from Chinese viewers, and containing imagery to which Chinese audiences would not have been used. ${ }^{(45)}$

The Global Times, notably, published an English-language editorial (46) after the Panel Report was published, in which it stated that foreign media enterprises could have a "fair share" of the Chinese entertainment market after the WTO verdict, which further reminded China that "opening up is a must." Global Times castigated the Chinese media sector for not having engendered sufficient competition, and that public demand was "poorly fed." The People's Daily surveyed a number of Chinese film enterprises, who were confident that they would be able to survive competition from Hollywood. Nonetheless, these articles remain limited to the film sector and to increasing import quantities of foreign products - exactly the measure that did not come under question in the WTO cases.

On the other end of the scale, the People's Daily (47) interviewed a spokesperson from Phoenix Television, stating that the Panel Report should not be interpreted as a US win, but rather as "generally favourable" ( zongtishang youli 总体上有利) to the US position. This was due to the fact that the film quota would remain in place, and that the distribution situation also would not change. Also, the People's Daily indicated that any appeal would have to be fought on issues of law, rather than fact. In another article on the same day, the People's Daily interviewed professor Zhu Wangkang of the National University of Singapore, who said that more open markets might not result in better results for foreign rights holders, as both their products and means of distribution might be unsuited to the Chinese market. ${ }^{(48)}$ On the other hand, the People's Daily also quoted the US-China Chamber of Commerce's statement that they hoped the US and China would jointly march towards freer trade. ${ }^{(49)}$

39. "Hollywood studio urges more film imports by China," China Daily, 25 December 2009.

40. See, for example: "Will the great film quota wall of China come down?," Guardian, 24 March 2011; "Has Hollywood cracked China?," Guardian, 27 September 2011; "Can Hollywood Afford to Make Films China Doesn't Like?," Time, 25 May 2011.

41. "Debate: Movie Quota," China Daily, 30 March 2011; "Jinkou dapian 'lang laile' yingye gongsi zhimian jingzheng," Xinhua, 23 March 2011.

42. Schedule of Specific Commitments on Services WT/ACC/CHN/49/Add.2

43. "Summary of US-China BilateralWTO Agreement," The White House Office of Public Liason, briefing, www.uschina.org/public/991115a.html (consulted on 7 March 2012).

44. "WTO chubanwu shichangzhunru an Meiguo zhan shangfeng," People's Daily, 14 August 2009.

45. "WTO zhengduan shili dao bi wenhua shichang gaige," Nanfang Daily, 16 August 2009.

46. "Editorial:WTO report challenges China's cultural market," Global Times, 14 August 2009.

47. "WTO chubanwu shichangzhunru an Meiguo zhan shangfeng," People's Daily, 14 August 2009.

48. "WTO cailing Zhongguo fangkuan yingyin chuban jinkou," People's Daily, 14 August 2009.

49. "Zhongmei chubanwu WTO zhengduan fuchu shuimian," People's Daily, 14 August 2009. 
The news website Sohu did not expect that this verdict would effect a programmatic change in China's programme of cultural structure reform, which had been launched in 2004, and aimed to ensure that China's cultural products would have a stronger impact at home and abroad. ${ }^{(50)}$ However, it was concerned that the verdict might have an adverse impact on the development of China's domestic film sector, and cited director Liu Miaomiao, who urged China to develop along a more realistic, low budget path, rather than confronting Hollywood's big budget megaproductions head-on. ${ }^{(51)}$ This sentiment was echoed in other media, who were concerned that China lacked the capacity, the "Star System" and the structural setup to compete with Hollywood. (52)

After the case closed, however, media attention became subdued, and less discussion was held in the Chinese press than in foreign newspapers. To a certain extent, this is not strange. There are a few institutionalized interests in China that could play the role of policy entrepreneurs ${ }^{(53)}$ for foreign media interests or media liberalization. Cinemas and film distributors, for example, would benefit from a larger amount of - usually high-grossing - foreign films on the market. The question, however, would be how the Chinese film sector would deal with this, given that it is often characterized as being underdeveloped, suffering from creative deficits, low income and growth opportunities, and badly hit by media piracy. A number of articles were published that gauged this potential impact. The Nanfang Daily, for example, ascribed the drive to attract more private investment into the film sector to WTO pressure. ${ }^{(54)}$ It also analysed how this might lead to more diversification in the film sector, amongst others the use of IMAX technology. ${ }^{(55)}$ The Global Times warned Chinese filmmakers to be more imaginative. ${ }^{(56)}$ One Apple fan site hoped that the verdict would mean that the iTunes service would be launched in China. ${ }^{(57)}$

In the press, as well, the foreign film trade does not seem to be a priority. In one article published the same week the $A B$ decision was announced, ten years of progress in the Chinese film sector were celebrated, without one mention of the WTO case, the influence or competition from foreign films. ${ }^{(58)}$ Another article in the same feature discussing foreign competition does not refer once to the potential increased competition after DS363. ${ }^{(59)}$ Rather, the month after the $A B$ decision, the film Avatar, which had become the highest-grossing film in Chinese cinema history, was pulled from cinemas, allegedly to reduce competition for an upcoming biographic film of Confucius, that had been heavily supported by the State (although the State Administration of Radio, Film and Television [SARFT] officially denied this). ${ }^{(60)}$

The English language newspaper China Daily, however, did keep the discussion on its pages, by reporting on negotiations to lift the quota, ${ }^{(61)}$ and discussing the potential implications in a cautiously positive light. (62) Also, it published interviews with Chinese filmmakers that were confident they would be able to withstand the influx of Hollywood films, ${ }^{(63)}$ and reported on the increasing amount and success of co-productions. ${ }^{(64)}$ The China Daily had advocated earlier for a relaxation of the film market, interviewing two academics arguing for opening. ${ }^{65)}$ Other news outlets, however, remained sceptical about change in media governance. This was illustrated in a special feature of Wangyi Entertainment, published around the implementation deadline. Here, interviews with film sector professionals made clear that the two State-appointed distributors, China Film Group and Huaxia, would remain in control of the film market. The WTO did not require the right to distribute to be opened to foreign enterprises, which also ensured Chinese private enterprises would not gain it. ${ }^{(66)}$

Moreover, by the second half of 2011, the public discourse on the media sector became increasingly politicized. The perceived weakness of the Chi- nese cultural sector had already spurred the leadership into designing increasingly grand development plans for cultural structure reform (wenhua tizhi gaige 文化体制改革). Also, there had been greater movements towards tighter control over different areas of society. Rights-defending lawyers and activists have been cracked down upon, as fears have arisen that China is abandoning its rule of law project. In April 2011, the well-known artist and activist Ai Weiwei was arrested and kept in detention for nearly three months.

In October 2011, the Central Committee issued a Decision ${ }^{(67)}$ in which it outlined the objectives and ideology for the entire cultural sphere. The core issue in this project was the establishment of a "core Socialist value system", which would "arm the Party and the People." Domestically, this meant that the priority became to optimize the attractiveness of the Party's message, and to diversify and improve the means through which it is disseminated As a result, more efforts would be poured into the construction of cultural infrastructure and "excellent cultural products" (wenhua jingpin 文化精品). This discourse contains a strong anti-internationalist discourse, at least on the importing side. While one of the key components of the cultural Decision is to expand China's international soft power and influence, ${ }^{(68)}$ little

50. For a collection of policy documents outlining this project, see the author's website China Copyright and Media, Structural Reform, http://chinacopyrightandmedia.wordpress.com/category/ structural-reform (consulted on 6 March 2012).

51. Sohu, Zhongmei wenhua chanye WTO zhengfeng shimo, wenhua shichang lang laile? [The Whole Story of the Sino-US Cultural Market Dispute, Has the Wolf Come in the Cultural Market?], 20 August 2009, retrieved 3 February 2012, Sohu, http://business.sohu.com/20090820/n266 115315.shtml (consulted on 6 March 2012).

52. Zhongfang huo jiu Zhongmei chubanwu shizhang zhunru'an shangsu WTO [The Chinese Side May Appeal to the WTO in the Sino-US Publications Market Access Case], 19 August 2009, China Intellectual Property News, www.cipnews.com.cn/showArticle.asp?Articleid=13025 (consulted on 6 March 2012)

53. Policy entrepreneurs are individual or organized actors that try to obtain outcomes favourable to them through actively engaging with different actors to put their issue on the agenda.

54. "Kuai lai, touzi guochan yingye!," Nanfang Daily, 29 January 2010.

55. "Teji zhi zheng, jumu zhi zheng, dianying shichang jiegou fenhua jiaju," Nanfang Daily, 6 August 2010.

56. "This year, the fight for the domestic market heats up," Global Times, 31 August 2011.

57. "iTunes yinyue shangdian wufa jinru Zhongguo?" [No Way for the iTunes Music Store to Enter China?], ChinaMac, 24 December 2009, www.chinamac.com/2009/1224/51624.html (consulted on 6 March 2012).

58. "Zhongguo dianying chanye fazhan 10 nian riyi fanrong, shangyehua cheng fazhan qushi" [The Development of the Chinese Film Industry has Flourished Daily for 10 Years, Commercialization Is the Development Trend], Sina, 18 December 2009, http://news.sina.com.cn/c/sd/2009-1218/131719289180.shtml (consulted on 6 March 2012).

59. "Zhongguo dianying zuihaode shiguang laile" [The Best Time for Chinese Film Has Come], Sina, 18 December 2009, http://news.sina.com.cn/c/sd/2009-12-18/131719289180_3.shtml (consulted on 6 March 2012).

60. "Guangdian zongju huiying xinwen, fouren 'Afanda' ranglu 'Kongzi'" [SARFT Replies to the News, Denies "Avatar" Makes Way for "Confucius"], People's Daily, 21 January 2010, http://media. people.com.cn/GB/40606/10810898.html (consulted on 6 March 2012).

61. Interview with MPAA chairman Christopher Dodd, "Change in film import quota is on the horizon," China Daily, 15 June 2011.

62. "Debate: Movie Quota," China Daily, 31 March 2011; "Opening-up of movie industry urged," China Daily, 10 February 2011.

63. "Master Blaster," China Daily, 27 October 2011.

64. "Seeing the big picture," China Daily, 17 November 2009.

65. "Foreign films 'would boost economy,'" China Daily, 19 June 2009.

66. "WTO caijue nan han Zhongguo yingshi, dapian yinjin reng xu guo shen" [WTO Verdict Hardly Shakes China's Film Market, Blockbuster Import Will Still Be Subject to Examination], Wangyi Entertainment, 26 March 2011, http://ent.163.com/special/yinjin (consulted on 6 March 2012).

67. Zhonggong Zhongyang Guanyu Shenhua Wenhua Tizhi Gaige de Jueding [Decision Concerning Deepening Cultural Structural Reform], Central Committee, 2011, A translation of this document is available on the author's web site: http://chinacopyrightandmedia.wordpress.com/2011/11/09/ central-committee-of-the-chinese-communist-party-decision-concerning-deepening-culturalstructural-reform (consulted 6 March 2012)

68. The Decision uses the term "to tower above the forest of nations" (yili yu shijie minzu zhi lin 屹 立于世界民族之林). 
emphasis is put on the receiving side, apart from cautioned and conditional language concerning "mutually beneficial" cultural exchange and learning from "the excellent cultural achievements of mankind." The militant language of the Decision was supplemented by a speech $\mathrm{Hu}$ Jintao gave to the $6^{\text {th }}$ Plenum of the Central Committee, which was later published in the Party policy magazine Qiushi. In this speech, Hu warned against the "long-term strategy" of "foreign hostile powers" that aimed to "Westernize and divide China."

The consequences of this Decision on the media sector became clear very soon, with the SARFT taking the lead. In a brief period of time, it issued a number of regulations, amongst others reducing the number of entertainment shows on satellite television channels, prohibiting advertising in television dramas, and limiting the amount of television dramas broadcast on provincial television channels. In an interview with the People's Daily ${ }^{(69)}$, a SARFT spokesperson stated that these measures were taken to enhance audience choice. In December, the State Council published a draft law ${ }^{(71)}$ for the promotion of the film sector. This law is aimed at lowering market access barriers, enhancing financial input into the film sector, but also at strengthening supervision and management. There are few provisions on import of foreign films, and no indication of market liberalization In other words, media sector reform in China at the moment is driven by central political considerations, in a direction of more control. Against this background, it is difficult to see how media enterprises could openly advocate more openness. Rather, it seems that the enterprises that are permitted to operate - and hence, co-opted into the power structure, are more interested in maintaining the status quo.

\section{The 2012 Deal}

In short, China's implementation of the DS363 conclusions was very limited, and the powerful media administration was driving developments in the cultural sphere towards stronger control and centralization, as well as rejection of foreign influence. However, given the deepening economic crisis and the need to engage China on other issues, and the difficulty of calculating appropriate values for retaliatory tariffs, ${ }^{(71)}$ there seems to have been a lack of political will in Washington to push strongly for a resolution. Nonetheless, it seems that the Chinese side wished to settle the matter, and in February 2012, a deal was struck between vice-Presidents Jo Biden and Xi Jinping, who was on his first visit to the White House. ${ }^{(72)}$ They agreed that a new quotum of 14 "special films" would be instituted on top of the 20-per-year commitment in the Services Schedule, and would give preference to films of which 3D and IMAX versions are available. Also, the portion of revenue going to the film studio would be raised from 13 percent to 25 percent. ${ }^{(73)}$

This deal was met with considerable enthusiasm on the US side, Vice-President Joe Biden said it would "make it easier than ever before for US studios and independent film-makers to reach the fast-growing Chinese audience." The deal would also save "thousands of American jobs in and around the film industry," and give Chinese audiences "access to more of the finest films made anywhere in the world." (74) MPAA Chairman Chris Dodd called it a "major step forward in spurring the growth of US exports to China." (75) At the Chinese side, there was a higher sense of confidence concerning the Chinese film industry's ability to meet the challenge of more US competition. In a feature on the agreement, the People's Daily stated that the relationship between the US and Chinese film industries was no longer one of "wolves and sheep" (lang he yang 狼和羊) (76). Rather, it argues that China is has already made a small number of products that can compete with Hollywood standards, and that this should push Chinese filmmakers to excel more ${ }^{(77)}$. Confirming this fact in a play on words, popular director Feng Xiaogang stated he was not afraid of the "Hollywood Tiger" ( haolaihu 好莱 虎 ). ${ }^{(78)}$ There were even some rumours about a third film import licence, for which a number of interested companies were preparing an application. ${ }^{(79)}$

From the trade point of view, however, this agreement is relatively disappointing. At the time of writing, the text of the agreement had not yet been published, but there might be questions concerning the position of this agreement in the WTO framework. As a bilateral agreement providing extra trade concessions, there might be a risk that the agreement would violate the MFN principle, ${ }^{(80)}$ unless the new quota are open to all foreign films. Moreover, although the absolute number of important films will go up, there are still rules concerning the proportion of screen time foreign movies are permitted to occupy. These remain at one-third of total screen time, which still limits the potential market for foreign films. Also, the agreement was negotiated by Xi jinping, and it is not clear to what extent SARFT or other media administrations, who will have to implement this agreement, were involved in this decision. This may have consequences for the way in which the film administration will expand access to foreign films. Given that SARFT had imposed further television broadcast limits for foreign television dramas a few days before the agreement was concluded, (81) it does not seem that the basic position vis-à-vis foreign entertainment products has changed. Also, SARFT communicated to the People's Daily that they had not yet been

69. "Guangdian Zongju jiu jinyibu jiaqiang dianshi shangxing zonghe pindao jiemu guanli dawen," Xinhua, 26 October 2011

70. Zhonghua Renmin Gongheguo dianying chanye cujin fa (zhengqiu yijian gao) [Film Industry Stimulation Law of the People's Republic of China (Opinion-Seeking Draft)], 2011.

71. Julia Ya Qin, "Pushing the Limits of Global Governance: Trading Rights, Censorship and WTO Jurisprudence - A Commentary on the China-Publications Case," op. cit.

72. "United States Achieves Breakthrough on Movies in Dispute with China," USTR, 18 February 2012, retrieved 20 February 2012, www.ustr.gov/about-us/press-office/press-releases/2012/february/ united-states-achieves-breakthrough-movies-disput (consulted on 6 March 2012).

73. "In China Movie Pact, More 3-D, Less Reality," The New York Times, 19 February 2012, retrieved 20 February 2012, www.nytimes.com/2012/02/20/business/media/more-3-d-less-reality-in-uschina-movie-pact.html (consulted on 6 March 2012).

74. USTR, "United States Achieves Breakthrough on Movies in Dispute with China", art. cit. 2012.

75. "White House Gets China To Open Market to U.S. Movies," Reuters, 18 February 2012, www.reuters.com/article/2012/02/18/idUS420251887620120218 (consulted on 6 March 2012).

76. "Meiguo dapian jinkou pei'e zengjia fencheng tigao, yuanxian: lirun tanbo" [American blockbuster import quotas increased and divisions raised, cinema chains: profit spread out thinly, People's Daily, 20 February 2012, http://haiwai.people.com.cn/GB//n/2012/0220/c232577-16769614.html (consulted on 6 March 2012).

77. "Zhongguo dianying xuyao xinde xiongxin he mengxiang" [Chinese Film Needs New Aspirations and Dreams], People's Daily, 20 February 2012, http://haiwai.people.com.cn/GB//n/2012/ 0220/c232574-16769469.html (consulted on 6 March 2012).

78. "Zhongguo yingren reyi WTO dianying xieyi, Feng Xiaogang bu pa 'Haolaihu'" [China Film People Hotly Debate the WTO Film Agreement, Feng Xiaogang Is Not Afraid of the "Hollywood Tiger," People's Daily, 20 February 2012, http://jx.people.com.cn/GB//n/2012/0220/c19030116767933.html (consulted on 6 March 2012).

79. "Anzhan disanzhang jinkoupian 'paizhao'" [Dark Battle for the Third Film Import "Plaque"], 21st Century Media, 21 February 2012, www.21cbh.com/HTML/2012-2-21/zNMDcyXzQwMzMz Nw.html (consulted on 6 March 2012).

80. The Most-Favoured Nation Principle is one of the core constituents of WTO law, and requires that nations treat all WTO members equally advantageously. See Article 1, General Agreements on Tariffs and Trade, 1947, and Article 2, General Agreement on Trade in Services, 1994.

81. Guanyu jinyibu jiaqiang he gaijin jingwai yingshiju yinjin he bochu guanli tongzhi [Notice Concerning Further Strengthening and Improving Foreign Television Drama Import and Broadcast Management], 2012. A translation of this document is available on the author's web site: http://chinacopyrightandmedia.wordpress.com (consulted 6 March 2012) 
informed about this decision the day after the agreement was made. ${ }^{(82)}$

Most importantly, this agreement does relatively little to address the underlying issues. The Agreement does very little to move towards freer trade for cultural products with China, and does not address the letter or the spirit of WTO rules and the DS363 decisions. Hence, it remains to be seen how long it will take until Hollywood will restart lobbying for more market access in China, for example in the field of online media retail. Given the fundamental disagreement about the economic and trade nature of cultural products between the United States and China, this is perhaps the only deal that could have been made. It seems to fit within the film administration's efforts to keep foreign content at bay, while attracting knowhow and technology deemed necessary to develop the Chinese film sector. Another manifestation of this line is the proliferation of film co-productions, ${ }^{\left({ }^{83}\right)}$ exemplified by an announcement that DreamWorks will open a joint venture animation studio in Shanghai. ${ }^{(84)}$

\section{Conclusion}

This essay aimed to provide more insight in the reception of WTO discipline in China in the field of cultural products and services. More specifically, it first analyzed the official Chinese discourse on the two WTO cases China - Intellectual Property Rights and China - Audiovisual, and compared it with the US discourse. Second, it aimed to understand the reaction and evaluation of the Chinese press, and contextualize it in the wider background of cultural policy. Third, it outlined the resolution eventually reached by both sides and the reaction thereto.

The official discourse shows that at least where these cases are concerned, China and the United States are working at cross-purposes, reflecting the basic divergence of their respective views of cultural products. The United States emphasize the rules-based nature of the WTO, the way in which they claim the Chinese measures at issue conflict with WTO discipline, as well as the limited nature of these cases in the whole of Sino-US relations. China, on the other hand, stressed the non-legal aspects of the dispute: the efforts that were made to conform to WTO requirements and the impact of the cases on the wider bilateral relationship, and the importance of censorship, even though China's right to censor never came under issue. Also, China flatly denied the factual basis for the findings of the Panel and the Appellate Body in China - Audio-visual, even after these had published their reports. While official discourse should not be accepted at face value, this divergence nonetheless shows that China, at least in these cases, has not been very apt in using the language and style of the international trading system. Given the politically sensitive context in which it operates, the WTO dispute settlement body has consistently taken a textualist and legalist line in applying WTO law. ${ }^{(85)}$ From the Chinese discourse, however, it seems that China considers the WTO to be a political institution rather than a legal one.

In the Chinese media, the cases weren't subjected to much attention outside of factual reporting. The few articles that appeared evaluated the impact of the cases on the media sector, tapping into the developing narrative of cultural structure reform, commercial development and international soft power that has become increasingly prioritized in recent years. With the exception of the People's Daily, most newspaper outlets are moderately positive about the prospects of the Chinese media market after liberalization, especially after the announcement of the 2012 deal. In particular, they emphasize Chinese filmmakers' capacity to better respond to the de- mands of Chinese audiences and the beneficial role of more competition. Arguments concerning free trade are not made.

During recent years, the shifting political climate has steered cultural policy into another direction, and it is quite clear that opening the door to foreign cultural imports, or expanding upon the minimal commitments in the Services Schedule, is not a priority. What does this tell us about Chinese participation in the WTO? On the one hand, considerable care should be taken to expand findings about one specific (and politically very sensitive) to the whole range of WTO-related issues, especially given the high priority China seems to have given to WTO compliance in other sectors. On the other hand, it does help to highlight the Chinese expectations about the role of the WTO and Chinese commitments and the limits thereof. The Chinese discourse, both official and in the press, shows that the leadership has seen WTO accession as an instrumental move to maintain economic growth, legitimacy and authority. As a correlation of that, it is not willing to open up the cultural sector to the extent demanded by the United States, and has avoided to fully implement the findings from China - Audio-visual. This is in itself not strange. WTO Members have been in incompliance with WTO discipline earlier, concerning copyright, ${ }^{(86)}$ hormone beef (87) and gambling services, ${ }^{(88)}$ amongst others, for domestic political reasons. A long as the member is willing to face potential retaliatory action, this is the end of the legal line as far as the WTO is concerned.

It does open interesting questions as to non-trade concerns in international trade law, which may be subject of research in law, but also political science. In China, we are faced with the problem that many of these issues are still very opaque, and that primary knowledge is lacking. Hence, detailed case studies about the relationships between domestic policymaking, interest groups, governance and international pressure are necessary to better understand the structures and processes driving Chinese behaviour. Also, and perhaps even more interesting, would be to place these Chinese issues in a comparative context, and analyse where and how Chinese practice resembles or diverges from practices in other nations, regions, cultures and political systems.

82. "Yingren reyi WTO dianying xieyi, shihengbianye haishi yuhuo chongsheng" [Film Persons Hotly Discuss WTO Film Agreement, A Field Littered with Corpses or a Rebirth after Trial By Fire?] Xinhua, 20 February 2012, http://www.gd.xinhua.org/newscenter/2012-02/20/content_24738159.htm (consulted on 6 March 2012).

83. See CMM Intelligence, China Film Co-Production Report: The Survivor's Guide, March 2012.

84. It may not be a coincidence that Dreamworks was the first company to succeed in establishing a cartoon joint venture. The success of the Dreamworks film Kung Fu Panda caused some introspection in China, as it was felt that US enterprises were able to use Chinese memes and create a globally successful product, whereas China had succeeded in doing so. "'Gongfu Xiongmao 2' piaofang mubiao 6 yi, women weishenme paibuchu 'Abao'?" ["Kung Fu Panda 2" Box Office Objective 600 Million, Why Can't We Film a "Po"?], Southern Metropolitan Daily, 28 May 2011, reprinted by Guangming Daily, http://e.gmw.cn/2011-05/28/content_2018274.htm (consulted on 6 March 2012).

85. This line itself has been subject of criticism. See, for example Magnuson, William, "WTO Jurisprudence \& Its Critiques:The Appellate Body's Anti-Constitutional Resistance," Harvard International Law Journal, vol. 51, 2010, pp. 121-154.

86. DS160, US - Section 110(5) Copyright Act.

87. DS26, EC - Hormones, and related DS320, US - Continued Suspension.

88. DS285, US - Gambling. 